\title{
ENGLISH LITERACY MANAGEMENT AT SMPI AL ABIDIN SURAKARTA
}

\author{
Fithriyah Nurul Hidayati \\ English Language Education Department, Institut Agama Islam Negeri Surakarta, \\ Sukoharjo, Central Java, Indonesia \\ Email: fithrinhidayati82@gmail.com
}

DOI: http://doi.org/10.33650/al-tanzim.v5i1.1623

\begin{tabular}{l|l|l} 
Received: December 2020 & Accepted: March 2021 & Published: March 2021
\end{tabular}

\begin{abstract}
:
This study aims to analyze the implementation of school management to improve students' English literacy at SMP Islam Al Abidin Surakarta. This study uses a qualitative approach with a phenomenological method. The process of seeking and finding information related to English literacy improvement management is carried out through the $5 \mathrm{~W}+1 \mathrm{H}$ process. The study results showed that the implemented school management consisted of steps that supported English literacy starting from planning, organizing, implementing and evaluating activities. 1) The planning steps is related to determining goals, objectives, designing literacy activity programs, 2) organizing the resource, 3) implementing related to English literacy is through the following programs: (a) English Development Program, such as: English Camp, English Festival, Saturday Performance, Every day is English day, and Five Minutes Presentation (b) Literacy Programs, such as: Reading, Listening, Speaking Time and 4) controlling of implementing English literacy.
\end{abstract}

Keywords: Management, Literacy, English

\begin{abstract}
Abstrak:
Kajian ini bertujuan menganalisis pelaksanaan manajemen peningkatan kemampuan literasi bahasa Inggris di SMP Islam Al Abidin Surakarta. Penelitian ini menggunakan pendekatan kualitatif dengan metode fenomenologis. Proses mencari dan menemukan informasi terkait manajemen peningkatan literasi bahasa Inggris dilakukan melalui proses $5 \mathrm{~W}+1 \mathrm{H}$. Hasil menunjukkan bahwa manajemen sekolah yang diimplementasikan terdiri atas langkah-langkah yang mendukung literasi bahasa Inggris dimulai dari kegiatan perencanaan, pengorganisasian, pelaksanaan hingga pengawasan. Langkah 1) perencanaan berkaitan dengan menentukan tujuan, sasaran, merancang program kegiatan literasi, 2) pengorganisasian sumber daya, 3) pelaksanaan kegiatan yang berkaitan dengan kemampuan literasi bahasa Inggris adalah dengan program: (a) Program Pengembangan Bahasa yaitu: English Camp, English Festival, Saturday Performance, Everyday is English day, dan Five Minutes Presentation. (b) Program literasi yaitu reading, listening, speaking time dan 4) pengawasan pelaksanaan literasi bahasa Inggris.
\end{abstract}

Kata Kunci: Manajemen, Literasi, Bahasa Inggris 


\section{INTRODUCTION}

In the teaching and learning practice, one skill that students need to acquire is information processing skill. The skill involves receiving, processing, and transforming information and messages into other forms. In other words, the skill is often called literacy competence. Reports from international research institutions such as PISA in 2015 stated that Indonesia ranked 64 out of 72 countries in term of literacy competence, putting the country in a not favourable position, specifically in reading and writing interests. For this reason, mainstreaming literacy competence needs to be implemented during the teaching and learning process. It is in line with the research conducted by Supardi, who suggests that students need to master basic ICT skills such as computer operational skills, software application skills, internet mastery, and web mastery in using social media (Supardi et al., 2021).

Literacy is related to understanding and communicating a message through text, both written and spoken (Wagner, 1993). It also emphasizes the ability to process and understand information obtained when writing or reading (Faizah \& Utami, 2016). Adequate literacy skills affect the development of thinking skills. Research has shown that there is a significant influence between scientific literacy and mastery of basic biological concepts, critical thinking skills with mastery of basic biological concepts, as well as scientific literacy and critical thinking skills (Juhji \& Mansur, 2020). Literacy skills help individuals comprehend information thoroughly and carefully. This skill plays a vital role in education to help students gain information and broaden their insights and knowledge (Septiary \& Sidabutar, 2020).

Literacy is not merely about reading and writing since other aspects need to be improved in literacy development (Keefe \& Copeland, 2015). It also involves the ability to understand, process and communicate through texts both spoken and written (Wagner, 1993). The UNESCO Prague Declaration in 2003 states literacy skills are related to the ability of individuals to communicate with other individuals or groups through science, language and culture (Wandasari, 2017)

The Ministry of Education and Culture conducted a study on student literacy competencies in 2019. Of the 6,500 students of grade 10 in 34 provinces, the student literacy competency level reached $61 \%$, and that means students' reading interest has increased from previous years. However, some things need to be improved in relation to student literacy skills including the quality of texts and the availability of reference books in schools. Introductions to more complex and complicated texts should be initiated to familiarize students with texts that require higher explorative and argumentative reasoning. (Kemendikbud, 2018). With the large number of open accesses and the wide availability of literature, students' exposure to high-quality texts will improve, and this exposure will increase not only their reading interest but also their critical thinking.

The Ministry of Education and Culture has rolled out a literacy movement since 2015 based on the Minister of Education and Culture Regulation Number 23 of 2015 concerning Character Development which aims 
to foster a culture of literacy in schools. One of the activities in the movement is a 15-minute activity of reading non-learning books before the start of study time. This activity aims to improve students' literacy skill to absorb and transform information thoroughly and wisely. The techniques used are reading aloud, guided reading, group reading, workshop, reading and writing comprehension, then the students are directed to the exploration stage (Kemendikbud, 2018).

Literacy skills, specifically English literacy, is needed since English has been recognized as a global language in international business, trade and transportation, international research, education and mass culture (Smith, 2009). The role of English is clearly defined and will remain an international language over time. Therefore, English literacy is needed for the future as it is one of the solutions to raise standards and develop human resources to face the globalization era (Khairuddiniyah, 2018).

English literacy opens up access to knowledge and technology. It also encourages students to communicate across culture or 'go global' because they have to connect with the world through digital books, online media and the internet. Furthermore, current literacy enables classroom language teaching in the local context intertwined with the global economy and global markets.

Referring to the Decree of the Minister of Education and Culture Number 19 of 2005 concerning National Education Standards, which emphasizes the improvement of English communicatively in schools or madrasah, the implementation of literacy strategy in English learning has become a must. There are four skills needed in English literacy: a high level of reading comprehension skills, proper writing skills, fluent and effective communication skills, and skills in operating various types of digital media (Arafik, 2017). Beyond the Blueprint: Literacy in grade and across the ccontent published by Connecticut State Department of Education (2007) divides literacy strategy into four categories: comprehension, vocabulary, fluency, and spelling (Khairuddiniyah, 2018).

The strategy implemented in schools to improve literacy culture is carried out in stages: Stage 1: Habitual fun reading activities in the school environment. Stage 2: Development of reading interest to improve literacy skills. Stage 3: Implementation of literacy-based learning. Beers, Beers, \& Smith (2009) suggests several strategies to create a positive literacy culture. Those strategies include building a physical literacy-friendly environment, establishing a social and affective environment to promote literate interaction and communication, and optimizing the role of schools as a literate academic environment. The time allocation for literacy habituation is 15 minutes before learning begins. This habituation includes reading aloud and silent reading.

As mentioned on the above theory, improving literacy culture at the student level is not solely the responsibility of the ministry of education as the top management of national education, but it is also the responsibility of educational institutions. Schools or madrasahs need to manage literacy so that it becomes a positive culture in schools. Fitriah (2018) suggests that in achieving educational objectives, especially students' literacy skills, a well-managed 
school organizational culture is needed. It requires cooperation, intensity, integrity and shared perceptions to accomplish certain goals in educational institutions. English literacy requires an appropriate education and school management system. Planning, implementing, and monitoring need to be paid close attention to program management so that program implementation can be carried out efficiently.

Instilling a culture requires a strong organizational system in order to ma nage existing resources in educational units such as students, teachers, administrative and education staff and school principals working together in the School Literacy Team which is supported by the Government Decree. The team then create a management system which consists of planning, implementing and monitoring the program to create a positive academic environment (Kemendikbud, 2018).

The literacy management process is carried out through four management functions, namely planning, organizing, actuating, dan controlling (Terry, 2003). Management activities cover a wide spectrum, because it starts from activities that determine the direction of the organization in the future, create organizational activities, encourage cooperation between fellow organizational members and supervise activities to achieve specific goals set by the organization (Wahyudin, Muslihah, \& Suryapermana, 2020). According to Fayol, there are five elements of management functions, namely planning, organizing, coordinating, commanding, and controlling (Fayol, 1995). The implementation of literacy management function aims to create a positive school environment to help students study in an orderly manner so the objectives of literacy activities can be achieved efficiently and effectively.

Literacy planning activities are carried out to prepare a series of decisions to take future actions directed towards achieving goals by utilizing optimum resources. The Planning includes activities to determine what to achieve, how to achieve it, how long, how many people involved and how much it will cost. Organizing literacy activities is done by grouping people and assigning tasks, functions, authorities and responsibilities to achieve the predetermined goals. The coordination of literacy activities includes arranging, unifying, harmonizing, integrating all activities carried out by the subordinates. Leaders in educational institutions need to provide a guidance in the form of brief instructions or explanations to their subordinates before and during the activities. This guidance is essential in building enthusiasm for the team members in carrying out their assigned tasks. Supervision of literacy activities is done by making corrections so the team members understand the right direction in doing their tasks based on the goals and objectives that have been initially set.

Previous studies on English literacy management in schools or madrasah, and one of which is a study from (Muhith, 2019), argues that the learning process, specifically literacy skills, requires planning on teaching and learning process as well as implementing a strong institutional management. Septiary \& Sidabutar (2020) examine the implementation of the School Literacy Movement or Gerakan Literasi Sekolah (GLS) which consists of planning, 
implementation, and evaluation activities. Fitriah (2018) examines the management of literacy culture in madrasas, starting with a planning process coordinated by the head of the madrasah, implementing literacy activities in the form of habituation of silent reading before learning, providing reading corners, programming bulan bahasa or language months, and establishing a scientific writing workshop. The program is then evaluated by the management team of madrasah and since the program is still on its early stage, the evaluation is anticipatory.

Solikhati \& Pratolo (2019) in their study concluded that English teachers should integrate digital literacy to improve students' foreign language literacy skills. Therefore English teachers must optimize the use of digital literacy in the classroom. Rosaline (2013) conducted a study on effective school management in the process of learning English at SMART Ekselensia Indonesia. The study aims to share ideas about the English language development program at SMART Ekselensia and its impact towards teachers and students. Rosaline's study is a descriptive study about preparation of teachers and students in international education programs by implementing English language development program. The results show that $90 \%$ of teachers and students are highly motivated to practice their English as often as possible.

However, these studies have not yet comprehensively examined the implementation of management functions starting from planning activities, organizing, implementing, to achieving the evaluation stage, especially in English literacy activities. It is important to study the implementation of management functions in English literacy activities, especially for teachers and students as the important elements of teaching and learning process. Planning, organizing, implementing, and evaluating are part of management to achieve a high level of students' literacy skills. Thus, the purpose of this article is to analyze the implementation of management at Al Abidin Islamic Junior High School in Surakarta as an attempt to improve students' English literacy skills.

\section{RESEARCH METHODS}

This research uses a qualitative approach. In qualitative research, there are four methods that can be used for human and social sciences research, namely: ethnographics, grounded theory, case studies and phenomenological studies. This study uses a phenomenological method, a research that emphasizes the identification of the essence of human experience about phenomena as described by the participants. Phenomenology describes the general meaning of a number of individuals to their various life experiences related to concepts or phenomena (Cresswel, 2012).

It can be stated that the phenomenological method is a qualitative research methodology used to obtain more in-depth data or phenomena experienced by participants. Based on the above description, the phenomenological study in this research is to collect data from research participants and to understand their perspectives on English literacy management at SMP Islam Al-Abidin Surakarta. 
The process of searching and finding information related to the improvement of English literacy management is done by applying the $5 \mathrm{~W}+1 \mathrm{H}$ questions: Who said it? The source of information must be clearly stated (students, teachers, school principals, or from the website): What did they say? What information is conveyed: Where did they say it? Where the information is conveyed: When did they say it? When was the information submitted: Why did they say it? Why the information was conveyed: How did they say it? How is the information conveyed?

\section{RESULT AND DISCUSSION Student English Literacy Management}

Based on the search on SMPI Al-Abidin Surakarta website at https://smpi.alabidin.sch.id, it shows that the school implements English literacy management by following some steps, namely planning, organizing, implementation, and supervision.

There are three main steps in planning English literacy improvement program at SMPI Al Abidin. These steps include setting goals, determining the targets for literacy program, and designing activities. The objectives of the activity: English literacy as a means of opening access to knowledge and technology, helping students to communicate in various cultures / being global because students need to be connected to the global world through digital books, online magazines, and the internet so that the vision of SMPI Al Abidin to become an international standard school can be achieved.

The targets of the activity are all students of Al Abidin Islamic Junior High School, Surakarta. The design of the activity covers English Development Program, English language improvement programs such as English Camp, English Festival, Saturday Performance, Every day is English Day, and Five Minutes Presentation. Literacy programs such as: Reading Time, Speaking Time, and Listening Time which are included in ICP class.

Interviews with Mr. Ahmad Sulaeman (2021), an English Teacher and a Manager of ICP Program at SMPI Al Abidin, draw the following results: Planning activities began by developing steps to achieve goals including forecasts, objective formulation, policy, programming, procedure, schedules, and budgeting.

The preparation of the program is intended to select activities that have been previously identified in policy steps. There are some considerations to follow: How much the activity will contribute to the achievement of targets, the possibility of the activity being implemented based on the available resources, the possibilities for the activities to be carried out on time, possible challenges during the process and ways to overcome the challenges.

Second step is the organization, which includes organizing team members who will be responsible for arranging the literacy management program. To ensure the success of the program, it is necessary to create a team to manage English literacy program. With the coordinators available in each team, and assisted by the English teachers, the program will run effectively. The person in charge of English Camp, English Festival programs is the Cambridge Program coordinator. While the person in charge of Saturday 
Performance program is an English teacher. Every day is English day program is coordinated by all teachers at SMPI Al Abidin, and Five Minutes Presentation program is under the responsibility of Class Teachers.

Mr. Ahmad Sulaeman (2021) an English Teacher and a Manager of ICP Program at SMPI Al Abidin, during the interview stated that organizing activity is done by assigning tasks and arranging students' structure during team coordination meeting, selecting students' coordinator for literacy program, dividing team members into the specified structures, allocating available resources, and establishing supportive conditions that allow people within the team to work cooperatively to achieve optimum results.

Third step is the implementation. SMPI Al Abidin has implemented various activities to support English literacy.

\section{Table 1 : Stages of English Literacy Activities}

\begin{tabular}{|c|c|c|c|c|}
\hline $\mathrm{N}$ & Component & Habitual Stage & Learning Stage & Development Stage \\
\hline 1 & $\begin{array}{l}\text { Basic } \\
\text { literacy }\end{array}$ & $\begin{array}{l}\text { Read for } 15 \\
\text { minutes before } \\
\text { class every day, } \\
\text { Reading aloud }\end{array}$ & $\begin{array}{l}\text { Discuss the } \\
\text { content of } \\
\text { English texts }\end{array}$ & $\begin{array}{l}\text { Write an analysis } \\
\text { of the text in } \\
\text { English }\end{array}$ \\
\hline 2 & $\begin{array}{l}\text { Library } \\
\text { literacy }\end{array}$ & $\begin{array}{l}\text { Search for literary } \\
\text { resources found in } \\
\text { the library as a } \\
\text { reading source for } \\
\text { 15-minute-reading } \\
\text { activity }\end{array}$ & $\begin{array}{l}\text { Include } \\
\text { bibliography } \\
\text { in English } \\
\text { assignments/ } \\
\text { tasks }\end{array}$ & $\begin{array}{l}\text { Use library as the } \\
\text { source of } \\
\text { information for } \\
\text { English reading } \\
\text { discussion. }\end{array}$ \\
\hline 3 & $\begin{array}{l}\text { Media } \\
\text { literacy }\end{array}$ & $\begin{array}{l}\text { Read news } \\
\text { from printed } \\
\text { / online media in } \\
\text { English for 15- } \\
\text { minute-reading } \\
\text { activity, } \\
\text { like Reading Time }\end{array}$ & $\begin{array}{l}\text { Discuss the } \\
\text { topics } \\
\text { presented in } \\
\text { printed / } \\
\text { online media }\end{array}$ & $\begin{array}{l}\text { Create a learning } \\
\text { community for } \\
\text { discussion and } \\
\text { information } \\
\text { sharing related to } \\
\text { English among } \\
\text { peers, teachers, } \\
\text { and schools }\end{array}$ \\
\hline 4 & $\begin{array}{l}\text { Technology } \\
\text { literacy }\end{array}$ & $\begin{array}{l}\text { Read English E- } \\
\text { book } \\
\text { as Reading Story Bo } \\
\text { ok }\end{array}$ & $\begin{array}{l}\text { Make use of } \\
\text { Information } \\
\text { Technology } \\
\text { during English } \\
\text { teaching and } \\
\text { learning }\end{array}$ & $\begin{array}{l}\text { Comment on } \\
\text { English E-books }\end{array}$ \\
\hline 5 & $\begin{array}{l}\text { Visual } \\
\text { literacy }\end{array}$ & $\begin{array}{lr}\text { Story } & \text { Sharing } \\
\text { Program } & \text { is a } \\
\text { program to share } \\
\text { stories } & \text { about } \\
\text { movies } & \text { using } \\
\text { English } & \end{array}$ & $\begin{array}{l}\text { Discuss English } \\
\text { movies }\end{array}$ & $\begin{array}{lr}\text { Use } & \text { visual } \\
\text { application } & \text { in } \\
\text { reporting } & \text { the } \\
\text { results } & \text { of } \\
\text { discussions } & \text { or } \\
\text { activities } & \end{array}$ \\
\hline
\end{tabular}


Table 1 shows that English literacy activities at Al-Abidin Islamic Junior High School in Surakarta are generally divided into two categories, the first is the Guidance for English Development Program and the second is the Literacy Program. The Guidance for English Development Program includes English Camp, which aims to improve students' confidence in English. This program is held for 5 days outside of school, and routinely held every year. The results of an interview with Ms. Atin Kurniawati (2021) an English teacher and staff of the Al Abidin Learning Center (ALC) indicated that the English Camp program is to enhance students' English skills, and as for the activities during the camp, students can join English language competitions, student performances, and language classes. Students are divided into several groups, with one supervisor, usually an English teacher in each group. Evaluation is carried out after each activity to assess the effectiveness of the program. Reports to the school foundation in terms of evaluation results are conducted by the Supervisors.

The English Festival Program is held annually. Activities offered in this program include competition between classes, and all students are required to participate in at least 1 competition such as: storytelling, newscaster, DIY (presentations on making handicrafts from used goods, laboratory projects, drama, treasure hunt (social and civics puzzles), English quiz (quiz), and listening. The program evaluation is conducted by the supervisor once the activity is completed. Then, the evaluation form is sent to the school foundation.

Saturday Performance Program aims to teach students to speak English in front of the public. Coordinator for this program is the Class Teacher. This activity is performed every Saturday morning before the Teaching and Learning Activities. Every week, there are 2 classes performing in this activity and class teacher acts as a Master of Ceremony. Students perform based on their creativity: performing drama, singing, giving speeches, playing music, and science experiments. Evaluation is done monthly by sending reports to the school foundation regarding the progress of the program.

English is every day aims to familiarize students with speaking English on a daily basis. The implementation of this program has not yet been fully optimized since it cannot be separated from other favorable programs, such as Tahfidz and ICT.

Five Minutes Presentation asks students to present a certain topic for each week, for example the topic about my pet. During the shift of one subject to the next, each student needs to present their theme, and their classmates are obliged to ask questions. Thus, there are two or three students that present their topics every day. Evaluations are held every month to figure out students' response related to the program.

The second one is the Literacy Program in the form of teaching and learning activities in the ICP class such as Reading time, Speaking Time, Listening Time, and the goal is to enhance students' literacy, such as Reading Story Books, Story Sharing Programs, Reading Aloud.

Supervision is well conducted with direct monitoring for each literacy activities, including a literacy monitoring, and a follow-up activity. To find out 
the effectiveness of an activity, an evaluation program is needed. Based on the explanation on the implementation above, it has already been mentioned in relation to the evaluation conducted by individuals responsible for each activity and the forms of evaluation for each activity.

The results of the interview show that the monitoring activities include determining standards or benchmarks for achievement which have been carried out with a program prepared at the beginning of the year, measuring results with existing standards through journals and materials that have been delivered, and assessing the literacy skills of both teachers and students. Supervision is also a comparison between the achievement of literacy skills by teachers and students by implementing predetermined steps, and taking the required steps to improve the results (Kurniwati, 2021).

There are several strategies applied in improving English literacy, such as: First, the teachers must understand the characteristics of all students. In Reading Time (Sharing Story Program, Reading aloud, Reading Story Book) and Speaking Time, teachers must pay attention to the characteristics of students such as their spoken language, experience, previous level of knowledge, vocabulary mastery, accuracy, and fluency. Second, the teachers must understand the linguistic characteristics of the selected text to support the learning content. Teachers must understand their role to create a learning environment that supports a literacy environment, familiarize reading activities in the school environment, develop reading interest in students by providing facilities and infrastructure that support a reading culture, and conducting a teaching and learning process that supports a literacy culture.

In terms of English literacy management program, Al Abidin Islamic Junior High School, Surakarta has implemented a well-structured management principle to foster a positive language learning culture and competence. In improving English literacy competencies, the school management has provided an optimal English extracurricular space by providing several programs such as English Development Program which consists English Camp, English Festival, Saturday Performance dan Five Minutes Presentation. This shows that this institution is committed to have a global vision in the future by facilitating their students to acquire skills that are globally recognized.

The learning program at this institution not only focuses on building a strong faith and piety for the students but also on science, languages and international networks. An excellent breakthrough in the management of educational institutions.

The results of the interview indicate that activities in English literacy at SMP Islam Al Abidin Surakarta are for students to be proficient in analyzing texts taken from English. In addition, it is also an effort to foster a culture of English literacy in schools, increase the reading interest for students and teachers to be literate with English reading books, create a fun and childfriendly school and make it as a garden of knowledge that enables students and teachers manage their knowledge and maintain sustainable learning by presenting various reading books and accommodating various reading strategies (Atin, 2021). 
Based on the research results, it can be seen that the management of improving English literacy skills at Al Abidin Islamic Junior High School in Surakarta starts from planning, organizing, and implementing to evaluation activities. The first step is planning activities which includes determining the objectives of the English literacy program for schools. The second step is the availability of human resources, facilities, infrastructure and program funding. The third step is program implementation. The fourth is evaluating the results of program implementation.

English literacy is essential as it is one step to instill a culture of literacy among people. The English literacy program is closely related to the culture of reading and writing which is the key access to knowledge and information.

\section{CONCLUSION}

Based on the above study, it can be concluded that the management implemented at SMPI Islam Al-Abidin Surakarta to support English literacy has been well-conducted, starting from planning, organizing, implementing and evaluating activities. Step 1) planning is related to determining goals, objectives, designing literacy programs, 2) organizing, 3) implementation related to English literacy skills through the following programs: (a) English Development Program such as: English Camp, English Festival, Five Minutes Presentation, Every day is English day, and Saturday Performance (b) Literacy program: through Reading, Speaking, Listening time activities held in class and 4) Supervision.

Considering the importance of technology in today's era, it forces individuals to be able to communicate internationally. It is suggested that SMPI Al Abidin improves its leading programs in the form of English Literacy so that students' English skills can be improved. English is an international language that is no longer a secondary need for education in Indonesia, instead it has transformed into a primary need to access knowledge and technology. English mastery ensures students' future in accessing higher level of study by applying scholarships or working globally.

The implication of this study is for other schools to participate in implementing the English literacy program, helping other schools to adopt the improvement of English literacy based on the activities described above. This study has limitations, including the limited time it has for data collection, so the data obtained is less optimal. This study merely describes the understanding of the school community towards English literacy, strategies and programs and their implementation, while the results of the evaluation of the literacy program cannot be described. 


\section{REFERENCES}

Arafik, M. (2017). The Implementation of Children Literature Instruction in Elementary School Advances, Economics, Business and Management Research. International Conference on Editional Management and Administration (CoEMA 2017), 277-281.

Beers, C. S., Beers, J. W., \& Smith, J. O. (2009). A Principle's Guoide to Literacy Insatruction. Newyork: Guilford Press.

Faizah, \& Utami, D. (2016). Panduan Gerakan Literasi Sekolah di Sekolah Dasar. Jakarta: Direktorat Jenderal Pendidikan Dasar dan Menengah Kemdikbud RI. Jakarta: Direktorat Jenderal Pendidikan Dasar dan Menengah Kemdikbud RI.

Fayol, H. (1995). Industrial and General Management. London: Sir Isac Pitman \& Sons.

Fitriah, N. (2018). Manajemen Pengembangan Kultural Literasi di MTs Negeri Kota Batu. Jurnal Manajemen Pendidikan Islam, 3(2), 63-71.

Juhji, J., \& Mansur, M. (2020). Pengaruh Literasi Sains dan Keterampilan Berpikir Kritis terhadap Penguasaan Konsep Dasar Biologi. Edusains, 12(1), 113-122. https:/ / doi.org/10.15408/es.v12i1.13048

Keefe, E., \& Copeland, S. (2015). Literacy Strategy for All Students: Accessingthe General Education Curriculum. Washington: The PEAL Center.

Kemendikbud. (2018). Desain Induk Gerakan Literasi sekolah. Jakarta: Direktorat Jenderal Pendidikan Dasar dan Menengah Kementrian Pendidikan dan Kebudayaan.

Khairuddiniyah, D. (2018). The Implementation of Literacy Strategies in Teaching English by the English Teacher at MAN Insan Cendekia Padang Pariaman. English Education: Jurnal Tadris Bahasa Inggris, 10(2), 242-257. https:// doi.org/10.2991/iconelt-17.2018.30

Muhith, A. (2019). Pembelajaran Literasi Membaca di Pondok Pesantren Sidogiri Kraton Pasuruan. Journal of Islamic Education Research, 1(1), 3450.

Rosaline, L. (2013). Preparing Teachers and Students of Smart Ekselensia Indonesia for International Education Through English Development Program. Jurnal Pendidikan Dompet Dhuafa, 3(2), 41-46.

Septiary, D., \& Sidabutar, M. (2020). Pelaksanaan Program Gerakan Literasi Sekolah (GLS) di SD Muhammadiyah Sokonandi. Epistema, 1(1), 1-12.

Solikhati, H. A., \& Pratolo, B. W. (2019). The Implementation of Digital Literacy in EFL Learning: A Case Study in SMP Muhammadiyah 1 Temanggung. Universitas Ahmad Dahlan.

Supardi, S., Juhji, J., Azkiyah, I., Muqdamien, B., Ansori, A., Kurniawan, I., \& Sari, A. F. (2021). The ICT basic Skills: Contribution to Student Social Media Utilization Activities. International Journal of Evaluation and $\begin{array}{lll}\text { Research in } & \text { 222-229. }\end{array}$ https://doi.org/10.11591/ijere.v10i1.20598

Terry, G. (2003). Prinsip-Prinsip Manajemeb. Jakarta: Bumi Aksara.

Wagner, D. A. (1993). Literacy and Development: Rationales, Assesment and Innovation. Philadelphia: National Centeron Adult Literacy. 
Wahyudin, W., Muslihah, E., \& Suryapermana, N. (2020). Pengertian, Ruang Lingkup Manajemen, dan Kepemimpinan. Jurnal Literasi Pendidikan Nusantara, 1(2), 111-124.

Wandasari, Y. (2017). Implementasi Gerakan Literasi Sekolah (GLS) sebagai Pembentuk Pendidikan Berkarakter. Jurnal Manajemen, Kepemimpinan, Dan Supervisi Pendidikan, 2(2), 325-342. 